\title{
Polymorphism of the bovine GH and LEP genes in a population of Slovak spotted bulls
}

\author{
Nina Moravčíková - Anna Trakovická \\ Slovak University of Agriculture in Nitra, Department of Animal Genetics and Breeding Biology, \\ Tr. A. Hlinku 2, 94976 Nitra, The Slovak Republic \\ nina.moravcikova1@gmail.com
}

Keywords: cattle, growth hormone gene, leptin gene, PCR-RFLP, polymorphism

\section{SUMMARY}

The aim of this study was the detection of polymorphism in the bovine growth hormone and leptin genes using the PCR-RFLP method. A polymorphic site of the growth hormone gene (AluI loci) that results in amino acid change at position 127 of the protein chain (leucine, L to valine, $V$ ) has been linked to differences in circulating metabolites, metabolic hormones and to milk yield. The polymorphism in bovine leptin gene is situated in the intron between two exons, which results in an amino acid change at position 2059 of the protein chain (cytosine, $C$ to thymine, T). The polymorphisms were studied in a group of 58 bulls of the Slovak spotted breed. A strategy employing PCR was used to amplify $428 \mathrm{bp}$ (GH gene) and $422 \mathrm{bp}$ (LEP gene) products from blood samples. Digestion of PCR products with restriction enzymes AluI and Sau3AI revealed alleles: L and V; $A$ and $B$ for $G H$ gene and LEP gene, respectively. The growth hormone gene is a candidate gene for body weight gain in cattle, since it plays a fundamental role in growth regulation. Leptin plays an important role in the regulation of feed intake, energy metabolism, growth and reproduction of cattle; therefore, animals with higher leptin gene expression will probably have lower daily weight gain than others with similar forage offer and nutritional condition and will also likely have longer calving intervals.

\section{INTRODUCTION}

Bovine growth hormone $(\mathrm{GH})$ is a single chain polypeptide with 190 or 191 amino acids and molecular weight $22 \mathrm{kDa}$. This hormone is produced in the anterior pituitary gland under the hypothalamic controls of two hormones: growth hormone releasing factor, which increases the secretion of $\mathrm{GH}$, and somatotropin releaseinhibiting factor, which inhibits its secretion (Nicoll et al., 1986). Growth hormone exerts its effects on growth and metabolism by interacting with specific receptors on the surface of target cells. Changes in the functional regions of the $\mathrm{GH}$ receptor can affect its binding capacity and signal pathway, and therefore alter the activity of GH in the target tissue (Stasio et al., 2005). The biological effects of GH involve a variety of tissue and metabolism of nutrient classes: carbohydrates, lipids, proteins and minerals. It is known that this hormone is the main regulator of postnatal somatic growth, stimulating anabolic processes such as cell division, skeletal growth and protein synthesis and is involved in nutrient partition by way of regulating the oxidation rate of fats (lipolytic activity), inhibition of glucose transport to peripheral tissues and the regulation of ribosomal activity involved in translation, which, in turn influences protein synthesis (Goodman, 1993). Therefore coordinated changes in tissue metabolism alter nutrient partitioning and thus play a key role in increasing growth performance or milk yield (Etherton and Bauman, 1998). In ruminants, GH is known to be responsible for galactopoesis and for the persistency of lactation (Svennersten-Sjaunja and Olsson, 2005). Because it is necessary for tissue growth, fat metabolism and homeorhesis; thus it has an important role in reproduction, lactation and normal body growth (Burton et al., 1994). Therefore, it has this important relationship; GH can be used as a candidate gene marker for improving growth, meat or milk production and for marked-assisted selection programs in cattle, too. The GH gene with approximately 1800 bp length, five exons and four introns is a part of a multiple gene family that contains prolactin and placental lactogenes and is assigned with chromosome region 19q26 in the bovine genome. Flanking repeat sequences of GH gene regulate the expression of a gene (Hediger et al., 1990).

It is known that alterations in nutritional states markedly influence GH secretion in both experimental animals and humans. The mechanisms whereby nutritional factors affect GH secretion had mostly been elusive until the recent discovery of leptin, the adipocyte-derived hormone (Zhang et al., 1994). In addition to playing an important role in energy homeostasis, leptin is also known to affect the secretion of various pituitary hormones, including GH (Casanueva and Dieguez, 1999). It has been reported that leptin stimulates the basal and growth hormone releasing factor (GRF)-induced GH secretion in rats. Several studies in vivo and in vitro suggested that these facilitatory actions of leptin may be mediated by GRF and somatostatin (SRIH), both of which represent principal hypothalamic peptides participating in the neuroendocrine regulation of GH secretion (Carro et al., 1999). Basal and GRF-induced secretion of GH is markedly reduced in obese animals and this is partially due to resistance to GRF at somatotropes. GH plays a vital role in regulating body weight by decreasing the synthesis of lipids and, therefore, decreased concentrations of GH would increase synthesis of lipids. In a negativefeedback loop, adipocytes, in turn, secret leptin, this communicates the amount of stored lipid to the brain. Leptin is, therefore, thought to act as a lipostat in regulating body weight. In support, concentrations of leptin are higher in obese than lean humans and sheep and leptin reduces appetite and body weight in rodents. Therefore, persistent obesity may result not only from resistance to GRF, but also from resistance to leptin (McMahon et al., 2001). 
Leptin (LEP) is a 16-kDa polypeptide hormone produced by adipocytes, and its expression is regulated by body fatness, energy balance, insulin, growth hormone and glucocorticoids (Leury et al., 2003). Leptin is expressed in a variety of other tissues, including placenta, mammary gland, skeletal muscle, gastric mucosa, brain and pituitary (Passos et al., 2007) and may also orchestrate and coordinate the reproductive status of an animal by acting as an intermediate molecule between nutrition and reproduction, monitoring the changes of nutritional states and probably recruiting additional molecules and hormones to regulate energy metabolism and reproduction (Chehab et al., 2002). LEP binds to a receptor mainly localized on Neuropeptid - Y - neurons, which in hypothalamus also appear to play a key role in the integration of feeding behavior with internal signals of body energy status. NPY is also involved in the control of reproductive function (Wayne et al., 1995). LEP is supposed to be the signal to the reproductive system that enough total energy, in from of fat, is present to support the added energy demands of a successful conception and pregnancy. LEP may help regulate ovarian development and steroidogenesis and serve as either a primary signal initiating puberty or as a permissive regulator of sexual maturation (Lindersoon et al., 1998). Dairy cows with poor body condition directly after parturition, experience reduced fertility and increased susceptibility to disease. Body condition in cattle has a high heritability and current research is focused on identifying candidate genes influencing this complex phenotype. Leptin is one such candidate gene; his receptors are localized, among others, in the regions of the hypothalamus where somatostatin and growth hormone releasing factor - two primary regulators of GH secretion - are produced (Leshin et al., 1994). The influence of LEP on the regulation of food intake and energy expenditure, as well as the location of his receptors, indicate its role in the growth processes (Barb et al., 1998). Receptors of LEP are expressed in a variety of cells and tissues, including the immune cells. Leptin is mainly involved in maintaining the energy balance by controlling food intake and energy expenditure and it regulates the endocrine and immune function (Houseknecht et al., 1998). In cattle, the LEP gene is located on chromosome 4. It consists of three exons and two introns, of which only 2 exons are translated into protein. The coding region of the LEP gene (501 nucleotide length) is contained in second exon and 3 which are separated by introns of approximately $2 \mathrm{~kb}$. The LEP gene promoter regions spans are approximately $3 \mathrm{~kb}$. This gene itself is considered a potentional QTL, influencing different production traits in cattle (Javanmard et al., 2010).

The aim of this study was conducted in order to identify the polymorphisms of growth hormone gene (AluI loci) and leptin gene (Sau3AI loci) in population of Slovak spotted bulls.

\section{MATERIAL AND METHODS}

In total, blood samples of 58 Slovak spotted bulls were taken. Genomic DNA was extracted from whole blood samples with isolation kit NucleoSpin Blood (Macherey-Nagel). Genotype analyses were performed using the polymerase chain reaction - restriction fragment length polymorphism (PCR-RFLP) method. A 428 bp fragment of exon 5 in bovine GH gene was amplified by PCR using forward and reverse primers according to Balogh et al. (2009) and PCR products of intron 2 in LEP gene with length $422 \mathrm{bp}$ were carried according to Liefers et al. (2002). The polymerase chain reaction for the GH and LEP gene was performed in a $25 \mu l$ reaction mixtures, containing: $10 \mathrm{x}$ PCR reaction buffer, $1.5 \mathrm{mM} \mathrm{MgCl}, 0.2 \mathrm{mM}$ dNTPs, 8 pM primers (Generi-Biotech), $1 \mathrm{U}$ Tag DNA polymerase (Fermentas) and $50 \mathrm{ng}$ genomic DNA. PCR amplification was carried out in C1000 ${ }^{\mathrm{TM}}$ thermal cycler (Biorad). Thermal cycling conditions included: an initial denaturation step at $94^{\circ} \mathrm{C}$ for $1 \mathrm{~min}$, followed by 30 cycles of $94^{\circ} \mathrm{C}$ for $30 \mathrm{sec}, 53^{\circ} \mathrm{C}$ for $30 \mathrm{sec}, 72^{\circ} \mathrm{C}$ for $30 \mathrm{sec}$ and a final extension at $72^{\circ} \mathrm{C}$ for 5 $\mathrm{min}$; at $95^{\circ} \mathrm{C}$ for $5 \mathrm{~min}$, followed by 35 cycles of $95^{\circ} \mathrm{C}$ for $30 \mathrm{sec}, 62{ }^{\circ} \mathrm{C}$ for $20 \mathrm{sec}, 72^{\circ} \mathrm{C}$ for $30 \mathrm{sec}$ and extension at $72^{\circ} \mathrm{C}$ for $7 \mathrm{~min}$ for $\mathrm{GH}$ and LEP genes, respectively. The PCR products of GH gene were digested with $1 \mu \mathrm{l}$ of FastDigest $\mathrm{AluI}$ (Fermentas) restriction enzyme at $37^{\circ} \mathrm{C}$ in time $15 \mathrm{~min}$ and products of LEP gene were digested with $1 \mu \mathrm{l}$ of FastDigest Sau3AI (Fermentas) restriction enzyme at $37^{\circ} \mathrm{C}$ in time 10 min. The digestion products were separated by horizontal electrophoresis in $3 \%$ agarose gels in $0.5 \times \mathrm{TBE}$ (130 V for 40 min) stained with GelRed (Biotium) prior to visualization under UV light (Table 1).

Table 1

Primer sequences of GH AluI loci and LEP Sau3AI loci

\begin{tabular}{cc}
\hline Locus & Primer sequence \\
\hline GH $A L U \mathrm{I}^{1}$ & F 5'-CGGACCGTGTCTATGAGAAGCTGAAG-3' \\
LEP Sau3AI ${ }^{2}$ & R 5'-GTTCTTGAGCAGCGCGTCGTCA-3' \\
& F 5'-TGG AGT GGC TTG TTA TTT TCT TCT- 3' \\
R 5'-GTC CCC GCT TCT GGC TAC CTA ACT- 3'
\end{tabular}

Note: $F=$ Forward, $\mathrm{R}=$ Reverse. ${ }^{1}$ Balogh et al. (2009), ${ }^{2}$ Liefers et al., (2002) 


\section{RESULTS}

Single nucleotide polymorphism (SNP) in the exon 5 of the bovine GH gene based on the use of restriction fragment length polymorphism was detected. The SNP in exon 5 (at codon 127) changes leucine to valine (GTC to GTG) in the mature GH molecule. It is a point mutation in position 2141. The digested LL PCR product exhibited four fragments of 265, 96, 51 and 16. For the VV genotype were exhibited 265, 147 and 16 bp. Figure 1. shows PCR product size and the restriction patterns of the tree genotypes LL, LV and VV. The results show, that the most frequent genotype for growth hormone gene in observed population was LV. The frequency of the $\mathrm{L}$ allele was 0.6404 and for B allele was 0.3596 in group of 57 Slovak spotted bulls. For this polymorphism of GH gene, three patterns were observed and their frequencies were $0.404(n=23), 0.473(n=27)$ and $0.123(n=7)$ for LL, LV and VV, respectively. Based on the observed vs. expected genotype frequencies, the whole pool was in a Hardy-Weinberg genetic equilibrium (expected genotype frequencies were LL $=0.410, \mathrm{LV}=0.4606$ and $\mathrm{VV}=0.1294)$.

Figure 1. Representative results PCR-RFLP analysis GH AluI loci on 3\% agarose gel

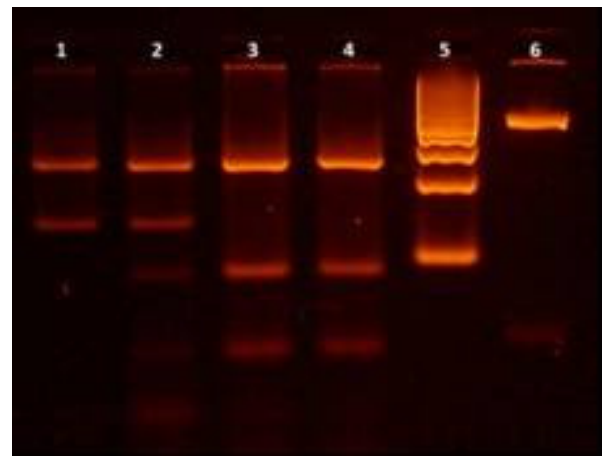

Line 1 is VV genotype (265, 147 and 16 bp), line 2 is LV genotype (265, 147, 96, 51 and 16 bp), line 3 and 4 are LL genotype $(265,96,51$ and $16 \mathrm{bp})$, line 5 is a marker of molecular weight (Fermentas, $100 \mathrm{bp})$ and line 6 is PCR product (428 bp)(Figure 1).

In the intron between two exons of the bovine LEP gene using digestion of PCR fragment with restriction enzyme Sau3AI was detected restriction fragment length polymorphism. There were two Sau3AI sites in $422 \mathrm{bp}$ fragments. The digested AA PCR product exhibited two fragments of 390 and $32 \mathrm{bp}$. For the BB genotype exhibited 303, 88 and 32 bp. Figure 2. shows PCR product size and the restriction patterns of the tree genotypes $\mathrm{AA}, \mathrm{AB}$ and $\mathrm{BB}$ and they confirmed mutation GAC»GAT (C to T) transversion. The frequencies of were 0.8017 and 0.1983 for A and B alleles, respectively. The most frequent genotype for LEPSau3AI loci in this observed population was AA. The number of individuals with different genotypes and allele frequencies for this polymorphism in leptin gene, so that three patterns were observed and frequencies were $0.638(n=37), 0.328$ $(\mathrm{n}=19)$ and $0.034(\mathrm{n}=2)$ for $\mathrm{AA}, \mathrm{AB}$ and $\mathrm{BB}$, respectively (Table 2).

Figure 2. Representative results PCR-RFLP analysis LEP Sau3AI loci on 3\% agarose gel

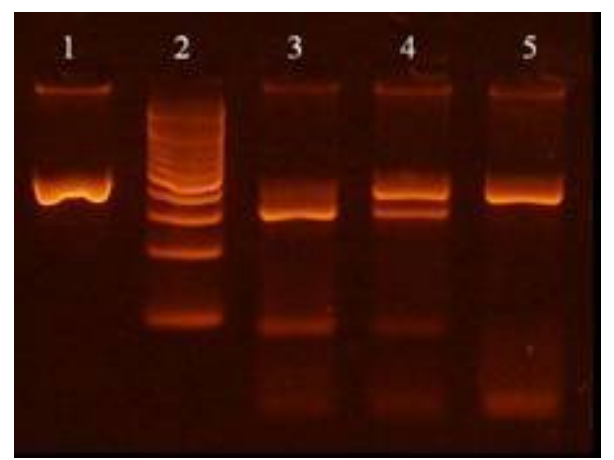

Line 1 is PCR product (422 bp), line 2 is a marker of molecular weight (Fermentas, $100 \mathrm{bp}$ ), line 3 is BB genotype (303, 88 and 32 bp), line 4 is AB genotype (390, 303, 88 and 32 bp) and line 5 is AA genotype (390 and $32 \mathrm{bp})$ (Figure 2). 
Gene and genotypic frequencies of GH AluI loci and LEP Sau3AI loci

\begin{tabular}{|c|c|c|c|c|c|c|c|c|c|c|}
\hline \multirow{3}{*}{ Bulls $(n=57)$} & \multicolumn{5}{|c|}{ GH AluI loci } & \multicolumn{5}{|c|}{ LEP Sau3AI loci } \\
\hline & \multicolumn{3}{|c|}{ Genotype } & \multicolumn{2}{|c|}{ Allele } & \multicolumn{3}{|c|}{ Genotype } & \multicolumn{2}{|c|}{ Allele } \\
\hline & LL & LV & VV & $\mathrm{L}$ & $\mathrm{V}$ & $\mathrm{AA}$ & $\mathrm{AB}$ & $\mathrm{BB}$ & $\mathrm{A}$ & $\mathrm{B}$ \\
\hline $\begin{array}{c}\text { Number } \\
\text { Frequency }\end{array}$ & $\begin{array}{c}23 \\
0.404\end{array}$ & $\begin{array}{c}27 \\
0.473\end{array}$ & $\begin{array}{c}7 \\
0.123\end{array}$ & 0.6404 & 0.3596 & $\begin{array}{c}37 \\
0.638\end{array}$ & $\begin{array}{c}19 \\
0.328\end{array}$ & $\begin{array}{c}2 \\
0,034\end{array}$ & 0.8017 & 0.1983 \\
\hline
\end{tabular}

\section{DISCUSSION}

The result of the present study showed that the GH AluI loci allele L was frequent than the $\mathrm{V}$ allele $(0.6404$ vs. 0.3596$)$, so that most of bulls (47.3\%) were heterozygous, $40.4 \%$ were homozygous for the leucine allele and only $12.3 \%$ were homozygous for the valine allele. A higher frequency of L allele (0.896) GH gene was reported for Holstein-Friesian cows (Balogh et al., 2009). These findings on allele and genotype frequencies were similar reported in study Lucy et al. (1993), Kovács et al. (2006), Silveira et al. (2008). Lucy et al. (1993) reported that the dairy breeds with the largest mature size (Holstein and brown Swiss) had the highest frequency of L allele, whereas smaller breeds (Ayshire and Jersey) had the highest frequency of V allele. Jakaria et al. (2009) reported, that the L allele frequency of GH AluI loci was higher for cattle with origin in Bos indicus than Bos taurus.

The A and B genetic variants of the Sau3AI polymorphism in the LEP gene were observed in this study. The A allele was most frequent than the B allele (0.8017 vs. 0.1983), so that most of the bulls $(63.8 \%)$ were homozygous for the A allele, $32.8 \%$ were heterozygous and $3.4 \%$ were homozygous for B allele. These findings were similar to those previously reported for Holstein-Friesian cows (Liefers et al., 2002), Black-and-White cows (Kulig et al., 2005), Holstein bulls (Javanmard et al., 2010) and different breeds of cows designed on meat yield (Passos et al., 2007). Pomp et al. (1997) verified that the frequency of a restriction fragment length polymorphism (RFLP) (Sau3AI) in bovine LEP gene was different between Bos Taurus and Bos indicus cattle breeds, it being possible that genotype differences in leptin could explain some of the phenotypic variation observed between breeds of cattle.

\section{CONCLUSIONS}

By using PCR-RFLP method have been detected genotypes in the polymorphic sites of growth hormone gene (AluI loci) and leptin gene (Sau3AI loci). In the studied population of 58 Slovak Spotted bulls were detected all three genotypes of GH AluI loci and the LL genotype $(n=23), \mathrm{LV}(\mathrm{n}=27)$ and VV $(n=7)$. The frequent allele in this population was allele $\mathrm{L}$ with observed frequency 0.6404. Of the bovine LEP gene were identified also three genotypes and the AA genotype $(n=37), A B$ genotype $(n=19)$ and BB genotype $(n=2)$. Allele A was in observed population most frequent $(0.8017)$ than the B allele.

\section{ACKNOWLEDGEMENT}

This work had financial support from project VEGA (project number 1/0061/10).

\section{REFERENCES}

Balogh O.-Kovács K.-Kulcsár M.-Gáspárdy A.-Zsolnai A.-Kátai L.-Péci A.-Fésüs, L.-Butler W.R.-Huszenicza G. (2009): AluI polymorphism of the bovine growth hormone $(\mathrm{GH})$ gene, resumption of ovarian cyclicity, milk production and loss of body condition at the onset of lactation in dairy cattle. Theriogenology, 71. 553-559.

Barb C.R.-Yan X.-Azain M.J. (1998): Recombinant Porcine Leptin Reduces Feed Intake and Stimulates Growth Hormone Secretion in Swine. Domest. Anim. Endocrinol, 15. 77-86.

Burton J.L.-McBride D.E.-Block E.-Glim D.R. (1994): A review of bovine growth hormone. Can. J. Anim. Sci., 74. 167-201.

Carro E.-Senaris R.M.-Seoane L.M.-Frohman L.A.-Arimura A.-Casanueva F.F.-Dieguez C. (1999): Role of growth hormone (GH)-releasing hormone and somatostatin on leptin-induced GH secretion. Neuroendocrinology, 69. 3-10.

Casanueva F.F-Dieguez C. (1999): Neruroendocrine regulation and actions of leptin. Front. Neuroendocrinol., 20. $317-363$.

Chehab F.F.-Qiu J.-Mounzih K.-Eward-Toland A.-Ogus S. (2002): Leptin and Reproduction. Nutr. Rev., 60. 39-46.

Etherton T.D.-Bauman D.E. (1998): Biology of somatotropin in growth and lactation of domestic animals. Physiol. Rev., 78. 745-761.

Goodman H.M. (1993): Growth hormone and metabolism. The endocrinology of growth, Development and Metabolism in vertebrates, 93115.

Hediger R.-Johnson S.E.-Barendse W.-Drinkvater R.D.-Moore S.S.-Hetzel J. (1990): Assignment of the growth hormone gene locus to 19q26-qter in cattle and to 11q25-qter in sheep by in situ hybridization. Genomics, 8. 171-174.

Houseknecht K.L.-Baile C.A.-Matteri R.L.-Spurlock M.E. (1998): the biology of leptin: a review. J. Anim. Sci, 76. $1405-1420$.

Jakaria R.-Noor R.-Martojo H.-Duryadi D.-Tappa B. (2009): Identification of growth hormone (Gh) gene MspI and AluI Loci Polymorphism in beef cattle. The $1^{\text {st }}$ International Seminar on Animal Industry 2009, Bogor, Indonesia. 42-46.

Javanmard A.-Khaledi K.-Asadzadeh N.-Solimanifarjam A.R. (2010): detection of polymorphisms in the bovine leptin (LEP) gene: association of single nucleotide polymorphism with breeding value of milk traits in Iranian Holstein Cattle. Journal of Molecular genetics, 2. 10-14. 
Kovács K.-Völgyi-Csík J.-Zsolnai A.-Györkös I.-Fésüs, L. (2006): Associations between the AluI polymorphism of growth hormone gene and production and reproduction traits in a Hungarian Holstein-Friesian bull dam population. Arch. Tierz., 49. 236-249.

Kulig H. (2005): Association between leptin combined genotypes and milk performance graits of Polish Black-and-White cows. Anim. Genet., 34. 371-374.

Leshin L.S.-Barb C.R.-Kiser T.E. (1994): Growth Hormone-Releasing Hormone and Somatostatin Neurons within the Porcine and Bovine Hypotalamus. Neuroendocrinology, 59. 251-264.

Leury B.J.-Baumgard L.H.-Block S.S.-Segoale N.-Ehrhardt R.A.-Rhoads R.P.-Bauman D.E.-Bell A.W.-Boisclair Y.R. (2003): Effect of insulin and growth hormone on plasma leptin in periparturient dairy cows. Am. J. Physiol. Regul. Integr. Comp. Physiol., 285. 11071115.

Liefers S.C-Pas M.F.W.-Veerkamp R.F.-Van der Lende T. (2002): Associations between leptin gene polymorphisms and production, live weight, energy balance, feed intake, and fertility in Holstein heifers. J. Dairy Sci., 85. 227-238.

Lindersoon M.-Andersoon-Eklund L.-De Koning D.J. (1998): Mapping of Serum Amylase-1 and Quantitative Trait Loci for Milk production Trait to Cattle Chromosome 4. J. Dairy Sci., 81. 1454-1461.

Lucy M.C.-Hauser S.D.-Eppard P.J.-Krivi G.G.-Clark J.H.-Bauman D.E.-Colier R.J. (1993): Variants of somatotropin in cattle: gene frequencies in major dairy breeds and associated milk production. Domest. Anim. Endocrinol., 10. 325-333.

McMahon C.D.-Radcliff R.P.-Lookingland K.J.-Tucker H.A. (2001): Neuroregulation of growth hormone secretion in domestic animals. Dom. Anim. Endocrinol., 20. 65-87.

Nicoll C.S.-Mayer G.L.-Russell S.M. (1986): Structural features of prolactin and growth hormones that can be related to their biological properties. Endocrinology Revue, 7. 169-203.

Pomp D.-Zou T.-Clutter A.-Barendse W. (1997): rapid communication: mapping of leptin to bovine chromosome 4 by linkage analysis of a PCR-based polymorphism. J. Anim. Sci., 75. 1427.

Pssos D.T.-Hepp D.-Moraes J.C.F.-Weimer T.A. (2007): Effect of polymorphisms linked to LEP gene on its expression on adipose tissue in beef cattle. J. Anim. Breed. Genet., 124. 157-162.

Silveira L.G.G.-Furlan L.R.-Curi R.A.-Ferraz L.J.- Alencar M.M.-Regitano L.C.A.-Martins C.L.- Arrigoni M.B.-Suguisawa L.-Silveira A.C.-Oliveira H.N. (2008): Growth hormone 1 gene (GH1) polymorphisms as possible markers of the production of beef cattle using the Brazilian Canchim breed as a model. Genetics and Molecular Biology, 31. 874-879.

Stasio L.D.-Destefanis G.-Brugiapaglia A.-Alberta A.-Rolando A. (2005): Polymorphism of the GHR gene in cattle and relationship with meat production and quality. Anim. Genet., 36. 874-879.

Svennersten-Sjaunja K.-Olsson K. (2005): Endocrinology of milk production. Domest. Anim. Endocrinol., 29. 241-258.

Wayne J.-Kuenzel W.J.-Fraley G.S. (1995): Neuropeptid Y: It is in the Neural Regulation of Reproductive Function and Food Intake in Mammalian species. Poultry Avian Biol. Rev, 6. 3. 185-209.

Zhang Y.-Proenca R.-Maffey M.-Barone M.-Leoppld L.-Friedman J.M. (1994): Positional cloning of the mouse obese gene and its human homologue. Nature, 372. 425-432. 